\title{
The role of plasma exchange in hyperbilirubinemia from a different perspective
}

\section{Farklı bir bakış açısı ille plazma değişiminin hiperbilirubinemideki rolü}

\author{
Hatice Terzi ${ }^{1}$, Serdal Korkmaz ${ }^{2}$, Mehmet Sencan ${ }^{1}$, Ozlem Yonem ${ }^{3}$, Abdulkerim Yilmaz ${ }^{3}$, Hilmi \\ Ataseven $^{3}$
}

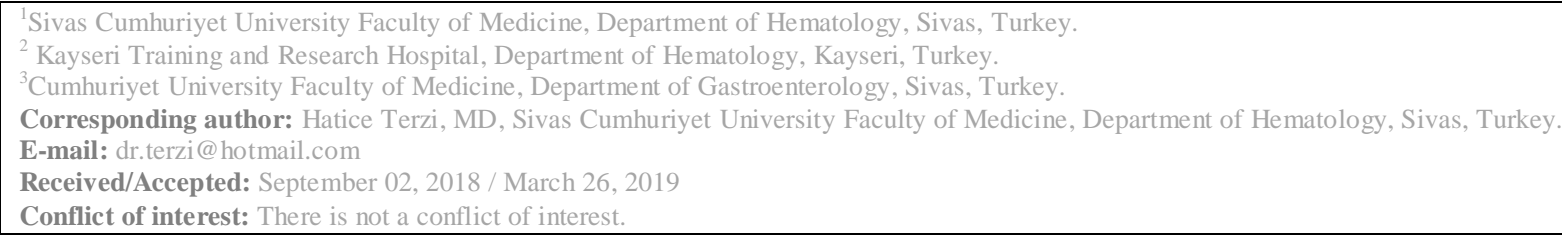

\section{SUMMARY}

Objective: In this retrospective study, we aimed to present our experience of managing hyperbilirubinemia. Method: Twenty three patients with hyperbilirubinemia who received apharesis treatment between 2006 and 2017 at the apheresis unit of Cumhuriyet University School of Medicine were included in the study. Records of the patients were evaluated retrospectively and the following data were collected: patient's age, sex, presenting symptoms, number of plasma exchange, adjuvant treatment modalities, use of replacement fluid, treatment outcomes, and plasma exchange complications.

Results: The median age of the patients was 57 years (range; 18-82). The median number of plasma exchange was 5,5 (range; 1-25). Fresh frozen plasma was the only replacement fluid used. There was significant statistical differences between pre- and post-plasma exchange bilirubine levels $(\mathrm{p}<0.05)$. Toxic hepatitis was the most common cause of hyperbilirubinemia in our patient population. In addition to plasma exchange, patients were treated with proper treatment of the underlying condition. We observed allergic reactions $2(8.69 \%)$ patients and hypotension in $3(13 \%)$ patients as complications

Conclusions: Plasma exchange is a safe method for the elimination of bilirubin. However, diminishing hyperbilirubinemia with plasma exchange together with the proper treatment of the underlying condition should be the primary goal in management.

Keywords: Fresh frozen plasma, Hyperbilirubinemia, Plasma Exchange

\section{ÖZET}

Amaç: Bu retrospektif çalışmada hiperbilirubinemiyi yönetme deneyimimizi sunmayı amaçladık.

Yöntem: Çalışmaya Sivas Cumhuriyet Üniversitesi Tıp Fakültesi aferez ünitesinde 2006-2017 yılları arasında aferez tedavisi alan 21 hiperbilirubinemili hasta alındı. Hastaların dosyaları retrospektif olarak değerlendirildi ve şu veriler toplandı: hastanın yaşı, cinsiyeti, semptomları, plazma değişimi sayısı, adjuvan tedavi yöntemleri, sıvı replasmanı kullanımı, tedavi sonuçları ve plazma değişim komplikasyonları.

Bulgular: Hastaların yaş ortalaması 57 idi (dağılım; 18-82). Ortalama plazma değişim sayısı 5,5'tir (aralık; 1-25). Sıvı değişimi için sadece taze donmuş plazma kullanıldı. Plazma öncesi ve sonrası değişim bilirubin düzeyleri arasında istatistiksel olarak anlamlı fark vardı $(\mathrm{p}<0.05)$. Toksik hepatit, hasta popülasyonumuzda en sık görülen hiperbilirubinemi nedeni idi. Hastalar plazma değişiminin yanı sıra, altta yatan durumuna uygun şekilde tedavi edildiler. Komplikasyon olarak, 2 hastada(\% 8.69) allerjik reaksiyon ve 3 hastada(\% 13) hipotansiyon gözlemledik.

Sonuç: Plazma değişimi, bilirubinin uzaklaştırılması için güvenli bir yöntemdir. Ancak, plazma değişimi ve altta yatan durumun uygun tedavisi ile birlikte azalan hiperbilirubinemi, tedavide birincil amaç olmalıdır.

Anahtar sözcükler: Taze donmuş plazma, hiperbilirubinemi, plazma değişimi 


\section{INTRODUCTION}

Hyperbilirubinemia is a common condition in daily practice. Many diseases, some of which are refractory and thus cannot be treated by medicines or surgery, cause hyperbilirubinemia. Thus, the prompt treatment is mandatory in some of these diseases. Hemoperfusion, hemodialysis, molecular adsorbent recycling system, and plasma exchange (PE) are effective methods in lowering high levels of bilirubin with fewer side effects ${ }^{1}$. Hyperbilirubinemia caused by different pathogenic factors can be treated by using the said methods or a combination of these methods based on symptoms, complications, and concomitant diseases. However, Liu et al., ${ }^{2}$ state that PE is superior in removing bilirubin than the other methods.

Bilirubin, endotoxin, and complement activator are removed and albumin, coagulation factors, and hepatic regenerative stimulating substance are replenished by $\mathrm{PE}$, which may correct the metabolic disorder ${ }^{1,3}$. PE, which is a procedure used since 1977 to support the liver, may alleviate hyperbilirubinemia, decrease mortality, and prolong survival time ${ }^{1,4}$. The aim of this retrospective study was to present the experience in managing hyperbilirubinemia.

\section{MATERIAL AND METHODS}

Twenty-three patients diagnosed with hyperbilirubinemia between 2006 and 2017 were evaluated retrospectively by reviewing their records at the Apheresis Unit of Sivas Cumhuriyet University School of Medicine. The inclusion criteria for the patients were having hyperbilirubinemia. The data such as the patient's age, gender, presenting symptoms, number of PE, adjuvant treatment modalities, replacement fluid, treatment outcomes, and PE complications were collected using an information form. Approval of the local Ethics Committee was obtained for the study which was conducted in accordance with the Declaration of Helsinki.

In general, hyperbilirubinemia is defined as total bilirubin level greater than $1.5 \mathrm{mg} / \mathrm{dL}$. In the present study, the reference ranges for total bilirubin and direct bilirubin were $0.3-1.2 \mathrm{mg} / \mathrm{dL}$ and $0-0.2 \mathrm{mg} / \mathrm{dL}$, respectively. In all patients, PE was initiated as soon as possible once a clinical and laboratory diagnosis of hyperbilirubinemia and the underlying disease was established. PE was performed by 1-1.5 plasma volume replacement once a day. The replacement fluid used was fresh frozen plasma. The bilirubin level was one of the major parameters on which the treatment decisions were based. PE was performed until the resolution of the underlying condition or when it was brought under control.

The plasma exchange procedures were carried out using one of the apheresis devices: Fresenius-AS 204, Fresenius COM-TEC, Haemonetic sMCS plus or Optia spectra. The procedure was performed by using a peripheral venous catheter in 8 patients and a central venous catheter in 8 patients. All vital signs were recorded as pre- and post-procedure. In the pre-procedure period, antihistamines and intravenous calcium gluconate were administered.

\section{Statistical analysis}

All the statistical analyses were performed using SPSS version 22.0 (SPSS, Chicago, IL, United States). The data which were not normally distributed were expressed as median values. The non-parametric Wilcoxon Signed Ranks test was used to test the differences between related (paired) samples. A p-value of $<0.05$ was accepted as statistically significant.

\section{RESULTS}

A total of 23 patients with hyperbilirubinemia [17 $(73,9 \%)$ males, $6(26,1 \%)$ females] were evaluated, retrospectively. The median age of the patients was 57 years (range; 18-82). The median number of PE was 5,5 (range; 1-25). FFP was used as the replacement fluid in all the experimental groups. Each procedure lasted for approximately 2 hours and the median plasma volume was 2000-2500 cc per procedure. Table 1 shows the baseline and post-plasma exchange laboratory characteristics of the patients. There were statistically significant differences between pre- and post-PE levels of Hemoglobin, pre- and post-PE bilirubin levels $(\mathrm{p}<0.05)$. Additionally, statistically significant differences were found in terms of BUN, creatine, $\mathrm{P}$, Total protein, albumin, AST, ALP, GGT, LDH, Hemoglobin, PT, APTT, and INR $(p<0.05)$. Table 2 summarizes the etiologies of the hyperbilirubinemias in the patient population of the present study. 
Table 1: The pre- and post-plasma exchange laboratory characteristics of patients

\begin{tabular}{|c|c|c|c|}
\hline Parameters & $\begin{array}{c}\text { Before Plasma Exchange } \\
\qquad \operatorname{median} \pm \mathrm{SD}\end{array}$ & $\begin{array}{c}\text { After Plasma Exchange } \\
\text { median } \pm \text { SD }\end{array}$ & $\mathrm{p}$ value \\
\hline $\mathrm{Hb}(\mathrm{g} / \mathrm{dL})$ & $12,52 \pm 2,00$ & $11,01 \pm 2,02$ & $0.001 *$ \\
\hline $\mathrm{WBC}\left(\mathrm{x} 10^{3} / \mu \mathrm{L}\right)$ & $7,39 \pm 2,84$ & $8,13 \pm 5,40$ & 0.491 \\
\hline Plt $\left(x 10^{3} / \mu \mathrm{L}\right)$ & $185,04 \pm 82,67$ & $211,87 \pm 99,36$ & 0.072 \\
\hline BUN (mg/dL) & $25,53 \pm 25,56$ & $23,52 \pm 23,87$ & $0.037 *$ \\
\hline Cre $(\mathrm{mg} / \mathrm{dL})$ & $1,42 \pm 1,36$ & $1,24 \pm 1,27$ & $0.016^{*}$ \\
\hline $\operatorname{ALT}(\mathrm{u} / \mathrm{L})$ & $200,83 \pm 341,88$ & $74,30 \pm 56,99$ & 0.064 \\
\hline AST (u/L) & $238,09 \pm 258,43$ & $130,13 \pm 134,85$ & $0.032 *$ \\
\hline GGT (u/L) & $139,22 \pm 108,62$ & $64,26 \pm 51,98$ & $0.001 *$ \\
\hline $\operatorname{ALP}(\mathrm{u} / \mathrm{L})$ & $237,91 \pm 148,66$ & $134,35 \pm 79,13$ & $0.001 *$ \\
\hline $\mathrm{LDH}(\mathrm{u} / \mathrm{L})$ & $443,70 \pm 457,15$ & $323,83 \pm 292,65$ & $0.013 *$ \\
\hline $\mathrm{Ca}(\mathrm{mg} / \mathrm{dL})$ & $8,68 \pm 0,75$ & $8,72 \pm 0,86$ & 0,738 \\
\hline $\mathrm{P}(\mathrm{mg} / \mathrm{dL})$ & $2,74 \pm 0,99$ & $3,29 \pm 1,22$ & $0.022 *$ \\
\hline T. prot $(\mathrm{g} / \mathrm{dL})$ & $5,53 \pm 0,70$ & $5,98 \pm 1,01$ & $0.024 *$ \\
\hline Alb (g/dL) & $2,82 \pm 0,60$ & $3,36 \pm 0,70$ & $0.001 *$ \\
\hline PT (second) & $17.42 \pm 5,87$ & $14,85 \pm 3,47$ & $0.014^{*}$ \\
\hline aPTT (second) & $34,13 \pm 5,76$ & $31,32 \pm 4,65$ & $0.021 *$ \\
\hline $\operatorname{INR}(\%)$ & $1.48 \pm 0,51$ & $1,28 \pm 0,323$ & $0.018^{*}$ \\
\hline T. Bil (mg/dL) & $23,95 \pm 10,11$ & $13,12 \pm 9,06$ & $0.001 *$ \\
\hline D. Bil (mg/dL) & $14,52 \pm 6,39$ & $8,26 \pm 6$ & $0.001 *$ \\
\hline
\end{tabular}

* means statistically significant

Hb: hemoglobin, WBC: white blood cells, Plt: platelet count, BUN: blood urea nitrogen, Cre: creatinine, ALT: alanine transaminase, AST: aspartate transaminase, GGT: gamma glutamyl transpeptidase, ALP: alkaline phosphatase, LDH: lactate dehydrogenase, $\mathrm{Ca}$ : calcium, P: phosphorus, T.prot: total protein, Alb: albumin, PT: prothrombin time, aPTT: activated partial thromboplastin time, INR: International normalized ratio, T. Bil: total bilirubin, D. Bil: direct bilirubin. 
Table 2. The underlying conditions of hyperbilirubinemia in the patient population

\begin{tabular}{lc}
\hline Etiology of hyperbilirubinemia & $\mathbf{n}(\%)$ \\
\hline Toxic Hepatitis & $9(39.1 \%)$ \\
Autoimmune Hepatitis & $1(4.35 \%)$ \\
Liver Cirrhosis & $1(4.35 \%)$ \\
Hepatocellular Carcinoma & $1(4.35 \%)$ \\
Hemochromatosis & $1(4.35 \%)$ \\
Sclerosing cholangitis & $1(4.35 \%)$ \\
Pacreas adenocarcinoma with liver metastasis & $1(4.35 \%)$ \\
Stomach adenocarcinoma with liver metastasis & $1(4.35 \%)$ \\
Idiopathic liver failure & $1(4.35 \%)$ \\
Adenocarcinoma of unknown primary & $1(4.35 \%)$ \\
$\begin{array}{l}\text { Choledocholithiasis } \\
\text { cancer ) }\end{array}$ & $3(13,05 \%)$ \\
\hline
\end{tabular}

Total

$23(\% 100)$

In addition to PE, the patients were treated for the underlying conditions. Nine patients had toxic hepatitis due to amoxicillin + clavulanic acid, anti-TNF agent, Helicobacter pylori treatment package (Amoxicillin + clarithromycin + lansoprazole), beta blocker, and anabolic steroids. The hyperbilirubinemia resolved with PE performed after interrupting these medications. One patient with liver cirrhosis was treated with PE and medications such as beta blocker, spironolactone, and furosemide. The said patient is still alive. One patient having autoimmune hepatitis was treated with PE and immunosuppressive therapy. One patient having sclerosing cholangitis was treated with $\mathrm{PE}$ and immunosuppressive therapy. The liver transplant was performed to the patients with sclerosing cholangitis and liver cirrhosis. Ursodeoxycholic acid was given to the patient with benign recurrent intrahepatic cholestasis (BRIC) by the plasma exchange. Plasma exchange has been still performed to the patient intermittently. To a patient with Stauffer syndrome (Paraneoplastic syndromes associated with prostate cancer), plasma exchange was performed in addition to LH-RH agonist, non-steroidal antiandrogen drug and radiotherapy. One patient with hepatocellular carcinoma (HCC) was treated with chemotherapy in addition to PE. The liver transplant was performed to the patient with $\mathrm{HCC}$ in his/her follow-ups. One patient with HCC is alive. Three patients with choledocholithiasis were treated with PE and intravenous antibiotics plus therapeutic endoscopic retrograde cholangiography.

The plasma exchange was performed to a patient with idiopathic liver failure for support purposes 
until the liver transplantation. Stents were placed by applying ERCP to 3 patients with liver metastasis including 1 stomach cancer, 1 pancreatic cancer and 1 adenocarcinoma of unknown primary; in the meantime, plasma exchange for the palliative purpose was performed. Since transferrin saturation was $93 \%$ in another patient who applied with liver enzyme elevation, HFE mutation was sent. The plasma exchange was performed due to high bilirubin until the genetic result was obtained. When HFE mutation was heterozygous positive, the patient started to be followed up by administering phlebotomy and iron chelation therapy (Hemochromatosis).

A total of seventeen patients $(73.8 \%)$ are still alive and are being followed up regularly by the department of gastroenterology.

In $5(21.73 \%)$ patients, there were complications related with the procedure. Allergic reactions in 2 $(8.69 \%)$ patients and hypotension in $3(13 \%)$ patients were the most common procedure-related complications. Most of these complications did not require any treatment or recovered with a simple medication such as antihistamines, and fluid infusion. No patient died because of these procedure-related adverse events.

\section{DISCUSSION}

Unconjugated bilirubin (UCB) develops as a result of the degradation of heme that derives mainly from the catabolism of erythrocyte hemoglobin. Increased production, decreased hepatic clearance, or enhanced enterohepatic circulation of the pigment may lead to unconjugated hyperbilirubinemia. In the liver, the enzyme bilirubin-UDP-glucuronosyltransferase conjugates UCB with glucuronic acid and generates conjugated bilirubin (CB) However, plasma UCB concentrations may rise to hazardous levels under specific conditions. Potential deposition of UCB in the central nervous system, causing bilirubin-induced neurological dysfunction, kernicterus, and death in the neonatal period, is the main reason behind the damage caused by severe unconjugated hyperbilirubinemia ${ }^{5}$. However, there is no known harmful effect of hyperbilirubinemia in adult life.

Hyperbilirubinemia is defined as total bilirubin exceeding $1 \mathrm{mg} / \mathrm{dL}$ in serum. It is a common finding encountered by most clinicians in daily practice. The only clinical manifestation of hyperbilirubinemia is jaundice seen especially in adults. Based on the underlying condition, UCB and/or $\mathrm{CB}$ or both increase. Altıntas et al., ${ }^{6}$ reported that malignancy was the major cause of jaundice. In the present study, it was found that toxic hepatitis was the most common cause of hyperbilirubinemia in the patient population.

Hyperbilirubinemias caused by different pathogenic factors should be treated by different methods such as hemoperfusion, hemodialysis, molecular adsorbent recycling system and PE, or by a combination of these methods ${ }^{1}$. Liu et al., ${ }^{2}$ stated that PE, hemoperfusion and molecular adsorbent recycling system could reduce bilirubin levels by $46.53 \%, 21.20 \%$, and $37.69 \%$ and blood ammonia by $19.04 \%, 15.35 \%$, and $44.13 \%$, respectively. In patients with hepatic encephalopathy, molecular adsorbent recycling system is a good option to reduce blood ammonia effectively. Hemodialysis may be used in patients having ascites and renal failure.

By using PE, a patient's plasma can be replaced with a donor plasma so that harmful substances in the bloodstream can be removed. PE also replaces the coagulating factors, albümin, and biologically active substances that are normally extracted by the liver cells ${ }^{7}$. In other words, it helps to maintain the biochemical and homeostatic balance in the body. By this method, the compensation of liver metabolism will lead to the necessary time for the patient's own liver regeneration to occur ${ }^{3 \text {, }}$ 8, 9 . In recent years, it has been shown that PE is effective in the emergency treatment of liver failure ${ }^{10-13}$.

It is important to treat the underlying condition not to lower bilirubin levels. PE probably removes deleterious substances such as autoantibodies in autoimmune hepatitis, ammonium in liver cirrhosis, and malignant cytokines and lowers bilirubin. Consequently, improving hyperbilirubinemia with $\mathrm{PE}$ and treating the underlying condition would be the most effective option as outlined in previous studies ${ }^{14}$.

In the present study, PE led to acute, rapid and significant reduction of plasma levels in hyperbilirubinemia. Being very effective, PE can be considered equivalent to an artificial liver that protects liver cells by reducing mitochondrial damage due to oxidative stress ${ }^{7,5}$. However, the target bilirubin level after PE therapy is still not clear. Similarly, there is no data about the length of $\mathrm{PE}$ procedure or the solution to be replaced while managing hyperbilirubinemia.

The present study had some limitations. The First limitation is that the present study did not include longitudinal observations but a retrospective design. The Second limitation is that the study 
was conducted with a relatively small size of the sample at a single-center. It is thought that prospective studies having more specific designs are required to enlighten the above-mentioned issues.

In conclusion, hyperbilirubinemia is a lifethreatening condition and PE is a suitable and safe method to eliminate bilirubin. PE, together with a proper treatment of any underlying condition, may allow sufficient time for regeneration of the liver. It is required to be outlined that hyperbilirubinemia is not a diagnosis, and lowering bilirubin should not be the primary goal. As the etiology of hyperbilirubinemia is the best predictor in terms of outcome, great effort should be made to treat the underlying cause.

\section{REFERENCES}

1. Duan $\mathrm{ZJ}, \mathrm{Li} \mathrm{LL}, \mathrm{Ju}$ J, et al. Treatment of hyperbilirubinemia with blood purification in China. World J Gastroenterol 2006; 12:746771.

2. Liu HB, Chen W, Dou KF, et al. Application of hemodialysis with plasma-based dialysate in patients with hyperbilirubinemia. J Nephrol Dialy Transplant 2004; 13:539-43.

3. Nakae H, Yonekawa T, Narita K, et al. Are proinflammatory cytokine concentrations reduced by plasma exchange in patients with severe acute hepatic failure? Res Commun Mol Pathol Pharmacol 2001; 109:65-72.

4. Larsen FS, Schmidt LE, Bernsmeier C, Rasmussen A, Isoniemi $\mathrm{H}$, Patel $\mathrm{VC}$, et al. High-volume plasma exchange in patients with acute liver failure: An open randomised controlled trial. J Hepatol. 2016 Jan;64(1):6978.

5. Shapiro SM, Definition of the clinical spectrum of kernicterus and bilirubin-induced neurologic dysfunction (BIND). J Perinatol 2005; 25:54-9.

6. Altıntaş E, Tombak A, Tellioğlu B, Ciddi hiperbilirubinemi nedenleri, tanı ve sağaltımı. Akademik gastroenteroloji dergisi 2010; 9(1):2-7.

7. Jin F, Cao M, Bai Y, et al. Therapeutic effects of plasma exchange for the treatment of 39 patients with acute fatty liver of pregnancy. Discovery Medicine 2012; 13:369-73.
8. Li M, Wang Z, Wang Y, Du C, Li S, Shi Z, et al. Part of plasmapheresis with plasma filtration adsorption combined with continuous hemodiafiltration in the treatment of severe acute liver failure. Exp Ther Med. 2016 Oct;12(4):2582-2584.

9. Nakamura T, Ushiyama C, Suzuki S, et al. Effect of plasma exchange on serum tissue inhibitor of metalloproteinase 1 and cytokine concentrations in patients with fulminant hepatitis. Blood Purif 2000; 18:50-4.

10.De Silvestro G, Marson P, Brandolese R, et al. A single institution's experience (1982-1999) with plasma-exchange therapy in patients with fulminant hepatic failure. Int $\mathbf{J}$ Artif Organs 2000; 23:454-61.

11.Ch'ng CL, Morgan M, Hainsworth I, et al. Prospective study of liver dysfunction in pregnancy in Southwest Wales. Gut 2002; 51(6):876-80.

12.Ho DW, Fan ST, To J, et al. Selective plasma filtration for treatment of fulminant hepatic failure induced by D-galactosamine in a pig model. Gut 2002; 50:869-76.

13.Shinozaki K, Oda S, Abe R, et al. Blood purification in fulminant hepatic failure. Contrib Nephrol 2010; 166:64-72.

14.Kamada N, Yoneyama K, Togawa Y, et al. Toxic epidermal necrolysis with severe hyperbilirubinemia: complete reepithelialization after bilirubin reduction therapies. J Dermatol 2010; 37:534-6.

15.Chu YF, Meng M, Zeng J, et al. Effectiveness of combining plasma exchange with continuous hemodiafiltration on acute Fatty liver of pregnancy complicated by multiple organ dysfunction. Artif Organs 2012; 36:5304. 